\title{
Assessment of Left Ventricular Hypertrophy and Dysfunction in Patients of Chronic Kidney Disease
}

\author{
Reetu Gupta', Ajay Kumar² \\ ${ }^{1}$ Post Graduate Student, Department of Medicine, TMMC \& RC, Moradabad, India, ${ }^{2}$ Professor, Department of Medicine, TMMC \& RC, Moradabad, India.
}

\section{Abstract}

Background: India experiencing an alarming increasing the burden of non-communicable diseases, like the prevalence of obesity and diabetes mellitus. Prevalence of CKD is also rising parallel but about this disease studied done infrequently, so the data on incidence of CKD is sparse. Cardiovascular disease can causing 50\% fatality in these patients irrespective of biological age. According to international registries death in dialysis population that are occurring due to cardiac disease occurring up to $40 \%$. Cardiovascular related morbidity and mortality that are associated with LVH is highly analytical for future progression that occurring in CKD patients.Subjects and Methods: This study was done in the Department of Medicine of TMMC \& RC, TMU, MORADABAD, U.P. it was a Cross-sectional Observational Study.100 cases will be taken from OPD and IPD setting in TMMC \& RC, TMU, Moradabad, U.P.Diagnosed cases of CKD patients aged $>18$ years of both sexes admitted in IPD or visiting to OPD in Teerthanker Mahaveer medical College \& Hospital, Moradabad. Those who were give valid consent.Cases below 18years of age, pregnant women. All cases of acute renal failure. All known primary case of IHD, CHF, RHD, Cardiomyopathies and any other cardiac disorders.Results:Majority (54.0\%) of sample were in the age group of 54 and above years, most $(64.0 \%)$ of them were males.It revealed that, the mean body weight of the sample was 55.0 $\pm 8.42 \mathrm{Kg}$, the mean Systolic Blood Pressure $(\mathrm{mmHg})$ of the sample was $144.56 \pm 19.88 \mathrm{mmHg}$. Mean Diastolic Blood Pressure $(\mathrm{mmHg})$ of the sample was $91.02 \pm 9.23 \mathrm{mmHg}$.ECG revealed that, around 65\% of the sample had LVH.2-D ECHO-LVH/LV Function reveled that, around 36\% AND 33\% of the sample have Mild concentric LVH and Moderate LV systolic dysfunction and LVH respectively.Majority (71.0\%) of the sample have reduced ejection fraction.Conclusion:Left ventricular hypertrophy and dysfunction is a veryimportant preventive feature of CKD associated cardiomyopathy. There is increased chance of left ventricular hypertrophy in CKD patients. With respect to category of chronic kidney disease, the LVH prevalence is progressively increases with increasing severity of CKD (chronic kidney disease).Blood pressure control is very important step to forestall the development of CKD and other related damage of end organs.

Keywords: Left Ventricular Hypertrophy, CKD.

Corresponding Author: Dr. Ajay Kumar, Professor, Department of Medicine, TMMC \& RC, Moradabad, India.

Received: December 2019

Accepted: December 2019

\section{Introduction}

India experiencing an alarming increasing the burden of noncommunicable diseases, like the prevalence of obesity and diabetes mellitus. Prevalence of CKD is also rising parallel but about this disease studied done infrequently, so the data on incidence of CKD is sparse. ${ }^{[1]}$

CKD confers increased risk for CHF, disease of coronary arteries or fatality in these individuals by the mostly cardiovascular reasons. ${ }^{[2]}$ In CKD patient's diastolic dysfunction of left ventricle occurring very often and related with the failure of heart (HF) with high fatality. ${ }^{[3]}$ Another studies shows that severity of CKD is causing impaired LV filling pressure along with impaired diastolic \& systolic function of heart in mostly predialysis patients and it is most autonomous predictor and could be answerable in these patients. ${ }^{[4]}$ Even in primary stages of kidney dysfunction LV diastolic dysfunction is seen. Either diastolic or systolic dysfunction can causing clinically
CHF. ${ }^{[5]}$ Systolic dysfunction of left ventricle is related with the severe coronary artery disease $\&$ it is play a factor for further progression of disease. ${ }^{[6]}$

Cardiovascular disease can causing $50 \%$ fatality in these patients irrespective of biological age. ${ }^{[7,8]}$ According to international registries death in dialysis population that are occurring due to cardiac disease occurring up to $40 \% .^{[9]}$ Patients with ESRD who starting on haemodialysis prevalence of these disease is very high in these patients, that suggesting that it might be occurring in CKD patients in large percentage since very initial stages. ${ }^{[10,11]}$ In, annual report year 1997 by 'US Renal Data System (USRDS)' revealed that in patients with chronic renal failure fatality occurring in $48 \%$ of cases by cardiac causes. ${ }^{[8]}$

$\mathrm{LVH}$ is an independent factor for fatality in patients who are on dialysis. ${ }^{[12,13]}$ Its occurrence is very high in ESRD patients who are on hemodialysis. ${ }^{[14]}$

Cardiac Left ventricular dilatation and hypertrophy is defined as (LVMi) in female $>100 \mathrm{~g} / \mathrm{m} \&$ in male $>131 \mathrm{~g} / \mathrm{m}$. LVH was detected in nearly $75 \%$ of patients at start of dialysis. ${ }^{[15]}$ 


\section{Gupta of Fhumar: Assessment of LVFH and Dysfunction in Patients of CKD}

The incidence of LVH in common population is $15-21 \%$ but it influences $50.0 \%-70.0 \%$ of patients during the intermediate stages of CKD and up to $90.0 \%$ of the patients with ESRD. ${ }^{[14,16,17,18]}$

According to the 'kidney disease improving global outcomes (KDIGO) CKD classification' cardio vascular related risk becoming very high particularly in stage $3 b-4$ class of renal disease and in those patients who are on renal replacement therapy. ${ }^{[19]}$

\section{$\underline{\operatorname{Aim}}$}

- To study LVH and dysfunction in patient of CKD.

\section{Objectives}

- Identify the LVH and LV dysfunction with ECG/ECHO and correlate with stages of CKD.

- Identify and correlate correctable causes of LVH.

\section{Subjects and Methods}

This study was done in the Department of Medicine, Teerthanker Mahaveer Medical College and Research Centre, (Moradabad) for one year period.

Study Setting: This study was done in the Department of Medicine of TMMC \& RC, TMU, MORADABAD, U.P.

Study Design: Cross-sectional Observational Study

Study Period:One year after approval from ethical committee.

Sampling Method: Purposive Sampling

Sample Size: 100 cases will be taken from OPD and IPD setting in TMMC \& RC, TMU, Moradabad, U.P.

Selection of Subject: Patients were selected on the basis of Inclusion \& Exclusion criteria.

\section{Inclusion Criteria:}

a) Diagnosed cases of CKD patients aged $>18$ years of both sexes admitted in IPD or visiting to OPD in Teerthanker Mahaveer medical College \& Hospital, Moradabad.

b) Those who were give valid consent.

\section{Exclusion Criteria:}

a) Cases below 18years of age.

b) Pregnant women.

c) All cases of acute renal failure.

d) All known primary case of IHD, CHF, RHD, Cardiomyopathies and any other cardiac disorders.

\section{Test Performed}

All subjects, relevant detailed history was obtained along with salient clinical findings according to the pre-designed proforma and laboratory reports of the patients was collected and analysed.

a. The patient was undergone following Investigations:

- Complete Blood Count

- Random blood sugar

- Kidney Function Test

- Spot urinary protein creatinine ratio/24-hour urinary protein

- ECG b. The patients than were subjected to resting 2-D transthoracic echocardiography and were be evaluated for

- Left atrium/Left ventricular dimension.

- Left ventricular hypertrophy.

- Left ventricular function.

- Ejection fraction.

- Pulmonary artery hypertension.

\section{Results}

The data presented in [Table 1] revealed that, majority $(54.0 \%)$ of sample were in the age group of 54 and above years, most (64.0\%) of them were males.

$43.0 \%$ sample having no formal education, around $96 \%$ of them were married.

Regarding their personal history, majority $(58.0 \%)$ of them were vegetarians, around $41.0 \%$ were smokers and about $72 \%$ of them were non- alcoholics.

Regarding past medical history, majority of them have hypertension, $48 \%$ of them are diabetic and only $3 \%$ of them had history of Tuberculosis.

Table 1: Frequency and Percentage Distribution of sample Characteristics $(\mathrm{N}=100)$

\begin{tabular}{|c|c|c|c|c|}
\hline \multicolumn{3}{|c|}{ Sample Characteristics } & $f$ & $\%$ \\
\hline \multirow{2}{*}{\multicolumn{2}{|c|}{ Age in years }} & $<53$ Years & 46 & 46.0 \\
\hline & & 53 and Above Years & 54 & 54.0 \\
\hline \multirow{2}{*}{\multicolumn{2}{|c|}{ Gender }} & Male & 64 & 64.0 \\
\hline & & Female & 36 & 36.0 \\
\hline \multirow{5}{*}{\multicolumn{2}{|c|}{ Education }} & No formal Education & 43 & 43.0 \\
\hline & & Middle school & 2 & 2.0 \\
\hline & & High school & 37 & 37.0 \\
\hline & & Intermediate & 7 & 7.0 \\
\hline & & Graduate & 11 & 11.0 \\
\hline \multirow{2}{*}{\multicolumn{2}{|c|}{ Marital status }} & Married & 96 & 96.0 \\
\hline & & Unmarried & 04 & 4.0 \\
\hline \multirow{2}{*}{\multicolumn{2}{|c|}{ Religion }} & Hindu & 65 & 65.0 \\
\hline & & Muslim & 35 & 35.0 \\
\hline \multirow{6}{*}{$\begin{array}{l}\text { Personal } \\
\text { History }\end{array}$} & \multirow[t]{2}{*}{ Dietary Pattern } & Vegetarian & 58 & 58.0 \\
\hline & & Mixed & 42 & 42.0 \\
\hline & \multirow[t]{2}{*}{ Smoking } & Smokers & 41 & 41.0 \\
\hline & & Non-smokers & 59 & 59.0 \\
\hline & \multirow[t]{2}{*}{ Alcoholism } & Alcoholic & 28 & 28.0 \\
\hline & & Non-Alcoholic & 72 & 72.0 \\
\hline \multirow{6}{*}{$\begin{array}{l}\text { Past Medical } \\
\text { History }\end{array}$} & \multirow[b]{2}{*}{ Hypertension } & Yes & 76 & 76.0 \\
\hline & & No & 24 & 24.0 \\
\hline & \multirow[b]{2}{*}{ Diabetes } & Yes & 48 & 48.0 \\
\hline & & No & 52 & 52.0 \\
\hline & \multirow[b]{2}{*}{ Tuberculosis } & Yes & 3 & 3.0 \\
\hline & & No & 97 & 97.0 \\
\hline
\end{tabular}

Table 2: General Examination of the sample (N=100)

\begin{tabular}{|l|l|}
\hline Parameters & Mean \pm SD \\
\hline Mean body weight & $55.0 \pm 8.42$ \\
\hline SBP $(\mathrm{mmHg})$ & $144.56 \pm 19.88$ \\
\hline DBP $(\mathrm{mmHg})$ & $91.02 \pm 9.23$ \\
\hline Heart Rate (per minute) & $86.89 \pm 6.42$ \\
\hline Pulse Rate (per minute) & $16.06 \pm 1.75$ \\
\hline Temperature (0F) & $97.46 \pm 0.91$ \\
\hline
\end{tabular}

The data presented in [Table 2] represents the mean and standard deviation of general examination parameters of sample. 


\section{Gupta of Fumar: Assessment of LVFH and Dysfunction in Patients of CKD}

It revealed that, the mean body weight of the sample was $55.0 \pm 8.42 \mathrm{Kg}$, the mean Systolic Blood Pressure $(\mathrm{mmHg})$ of the sample was $144.56 \pm 19.88 \mathrm{mmHg}$.

Mean Diastolic Blood Pressure $(\mathrm{mmHg})$ of the sample was $91.02 \pm 9.23 \mathrm{mmHg}$.

Table 3: Laboratory investigation of the sample $(\mathrm{N}=100)$

\begin{tabular}{|l|l|l|}
\hline Investigation & Mean \pm SD \\
\hline Blood Investigation & Hemoglobin $(\mathrm{gm} \%)$ & $9.19 \pm 2.35$ \\
\cline { 2 - 3 } & Total leucocyte count & $12857.64 \pm 5190.13$ \\
\hline \multirow{3}{*}{$\begin{array}{l}\text { Kidney Function } \\
\text { Test }\end{array}$} & Urea $(\mathrm{mg} / \mathrm{dl})$ & $129.74 \pm 66.09$ \\
\cline { 2 - 3 } & Serum creatinine $(\mathrm{mg} / \mathrm{dl})$ & $5.77 \pm 4.35$ \\
\cline { 2 - 3 } & Serum sodium $(\mathrm{mmol} / \mathrm{L})$ & $138.04 \pm 5.35$ \\
\cline { 2 - 3 } & Serum potassium $(\mathrm{mmol} / \mathrm{L})$ & $4.69 \pm 0.87$ \\
\hline
\end{tabular}

The data presented in [Table 3] represents the mean and standard deviation of Laboratory investigation of the sample including blood investigation and kidney function test.

It reveled that the mean Hemoglobin ( $\mathrm{gm} \%)$ of the sample was $9.19 \pm 2.35 \mathrm{gm} \%$,

The mean urea $(\mathrm{mg} / \mathrm{dl})$ value of the sample was $129.74 \pm 66.09 \mathrm{mg} / \mathrm{dl}$.

The mean Serum creatinine $(\mathrm{mg} / \mathrm{dl})$ value of the sample was $5.77 \pm 4.35 \mathrm{mg} / \mathrm{dl}$.

The mean Serum sodium $(\mathrm{mmol} / \mathrm{L})$ value of the sample was $138.04 \pm 5.35 \mathrm{mmol} / \mathrm{L}$

The mean Serum potassium $(\mathrm{mmol} / \mathrm{L})$ value of the sample was $4.69 \pm 0.87 \mathrm{mmol} / \mathrm{L}$.

Table 4: Frequency and Percentage Distribution of sample based on other investigations. $(\mathrm{N}=\mathbf{1 0 0})$

\begin{tabular}{|c|c|c|c|}
\hline \multicolumn{2}{|c|}{ Sample Characteristics } & $f$ & $\%$ \\
\hline \multirow[t]{4}{*}{ Category of Anemia } & Severe anemia & 19 & 19.0 \\
\hline & Moderate anemia & 24 & 24.0 \\
\hline & Mild anemia & 47 & 47.0 \\
\hline & Normal & 10 & 10.0 \\
\hline \multirow{3}{*}{$\begin{array}{l}24 \mathrm{hr} \text {.urinary } \\
\text { protein/spot urinary } \\
\text { protein creatinine ratio }\end{array}$} & A1 & 0 & 0 \\
\hline & $\mathrm{A} 2$ & 29 & 29.0 \\
\hline & A3 & 71 & 71.0 \\
\hline \multirow[t]{2}{*}{ ECG-LVH } & LVH & 65 & 65.0 \\
\hline & No LVH & 35 & 35.0 \\
\hline \multirow[t]{6}{*}{ Chest X-ray } & Within normal limit & 44 & 44.0 \\
\hline & Cardiomegaly & 50 & 50.0 \\
\hline & $\mathrm{B} / \mathrm{L}$ basal infiltration & 2 & 2.0 \\
\hline & $\mathrm{B} / \mathrm{L}$ mild pleural effusion & 1 & 1.0 \\
\hline & B/L Pleural effusion & 1 & 1.0 \\
\hline & $\mathrm{B} / \mathrm{L}$ infiltrate, cardiomegaly & 2 & 2.0 \\
\hline \multirow{7}{*}{$\begin{array}{l}\text { 2-D ECHO-LVH/LV } \\
\text { Function }\end{array}$} & Concentric LVH & 5 & 5.0 \\
\hline & Mild concentric LVH & 36 & 36.0 \\
\hline & $\begin{array}{l}\text { Moderate LV systolic } \\
\text { dysfunction and LVH }\end{array}$ & 33 & 33.0 \\
\hline & $\begin{array}{l}\text { Severe LV systolic } \\
\text { dysfunction and LVH }\end{array}$ & 7 & 7.0 \\
\hline & Global hypokinesia & 11 & 11.0 \\
\hline & Dilated LV/LA & 1 & 1.0 \\
\hline & Normal echo & 7 & 7.0 \\
\hline \multirow[t]{2}{*}{ Ejection Fraction } & Preserved & 29 & 29.0 \\
\hline & Reduced Ejection Fraction & 71 & 71.0 \\
\hline \multirow{2}{*}{$\begin{array}{l}\text { On Maintenance } \\
\text { Hemodialysis }\end{array}$} & Yes & 41 & 41.0 \\
\hline & No & 59 & 59.0 \\
\hline
\end{tabular}

The data presented in [Table 4] reveled that, majority $(47.0 \%)$ of the sample had mild anemia, $19 \%$ of the sample had severe anemia.

$71.0 \%$ of the sample had A3 Category of 24hr.urinary protein/spot urinary protein creatinine ratio.

ECG revealed that, around $65 \%$ of the sample had LVH.

Chest X-ray revealed that, $50.5 \%$ of the sample has Cardiomegaly.

2-D ECHO-LVH/LV Function reveled that, around $36 \%$ AND $33 \%$ of the sample have Mild concentric LVH and Moderate LV systolic dysfunction and LVH respectively. Majority $(71.0 \%)$ of the sample have reduced ejection fraction.

$41 \%$ of patients were on Maintenance Hemodialysis.

The data presented in [Table 5] represents the stages of CKD based on GFR $\mathrm{ml} / \mathrm{min}$ and it revealed that

$7 \%$ of the sample were in the stage 2 CKD.

$14 \%$ of the sample were in stage 3 CKD.

$17 \%$ of the sample were in the stage 4 CKD.

$(62 \%)$ of them were in stage 5 CKD.

Table 5: Frequency and Percentage Distribution of sample
based on stages of CKD. (N=100)
\begin{tabular}{|l|l|l|}
\hline CKD Stages & GFR Range & Frequency (\%) \\
\hline Stage 1 & $\begin{array}{l}\text { Signs of mild kidney disease with } \\
\text { normal or better GFR; GFR>90\% }\end{array}$ & $0(0.0)$ \\
\hline Stage 2 & $\begin{array}{l}\text { Mild kidney disease with reduced } \\
\text { GFR, GFR60-89\% }\end{array}$ & $7(7.0)$ \\
\hline Stage 3 & $\begin{array}{l}\text { Moderate chronic renal } \\
\text { insufficiency; GFR 30-59\% }\end{array}$ & $14(14.0)$ \\
\hline Stage 4 & $\begin{array}{l}\text { Severe chronic renal insufficiency; } \\
\text { GFR 15-29\% }\end{array}$ & $17(17.0)$ \\
\hline Stage 5 & $\begin{array}{l}\text { End stage renal disease; GFR } \\
\text { <15\%) }\end{array}$ & $62(62.0)$ \\
\hline
\end{tabular}

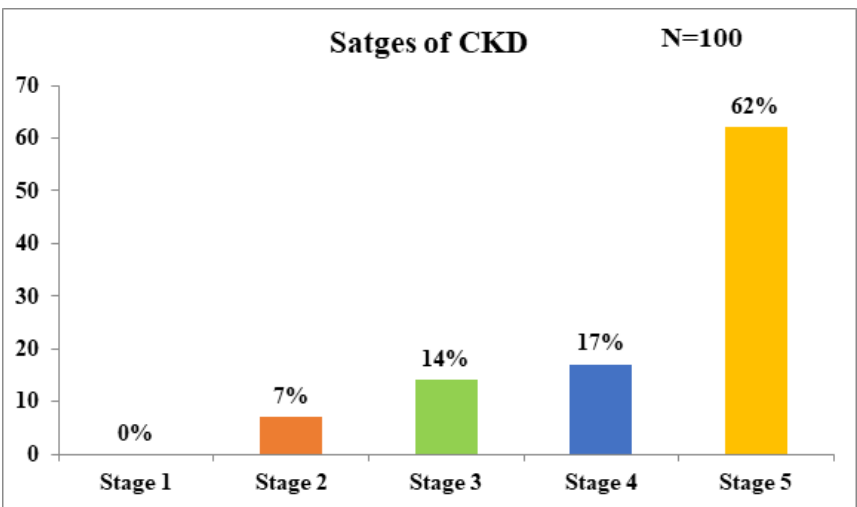

Figure 1: Bar graph showing percentage distribution of sample based on stages of CKD.

Table 6: Data comparing of severity of CKD with presence of LVH based on ECG. $(\mathrm{N}=100)$

\begin{tabular}{|c|c|c|c|c|}
\hline \multirow[t]{2}{*}{ Stages of CKD } & \multicolumn{2}{|c|}{ LVH } & \multicolumn{2}{|c|}{ No LVH } \\
\hline & $f$ & $\%$ & $f$ & $\%$ \\
\hline Stage 1 & 0 & 0.0 & 0 & 0.0 \\
\hline Stage 2 & 1 & 1.0 & 6 & 6.0 \\
\hline Stage 3 & 3 & 3.0 & 11 & 11.0 \\
\hline Stage 4 & 7 & 7.0 & 10 & 10.0 \\
\hline Stage 5 & 54 & 54.0 & 8 & 8.0 \\
\hline
\end{tabular}

The data presented in table 6 revealed that, $1 \%$ of stage 2 CKD cases had LVH and $6 \%$ of stage 2 CKD cases were not having $\mathrm{LVH}, 3 \%$ of stage $3 \mathrm{CKD}$ cases had LVH and $11 \%$ of stage 3 CKD cases were not having $\mathrm{LVH}, 7 \%$ of stage 4 CKD cases had LVH and $10 \%$ of stage 4 CKD cases were not having LVH and around 54\% of stage 5 CKD cases had 
$\mathrm{LVH}$ and $8 \%$ of stage $5 \mathrm{CKD}$ cases were not having $\mathrm{LVH}$

Table 7: Data comparing of severity of CKD with condition of ejection fraction $(\mathrm{N}=100)$

\begin{tabular}{|l|l|l|l|l|}
\hline \multirow{2}{*}{$\begin{array}{l}\text { Stages of } \\
\text { CKD }\end{array}$} & \multicolumn{4}{|c|}{ Ejection Fraction } \\
\cline { 2 - 5 } & \multicolumn{2}{|c|}{ Preserved (n=29) } & $\begin{array}{l}\text { Reduced Ejection Fraction } \\
(\mathbf{n = 7 1})\end{array}$ \\
\cline { 2 - 5 } & $\boldsymbol{f}$ & $\%$ & $\boldsymbol{f}$ & $\%$ \\
\hline Stage 1 & 0 & 0.0 & 0 & 0.0 \\
\hline Stage 2 & 4 & 17.1 & 3 & 64.3 \\
\hline Stage 3 & 5 & 35.7 & 9 & 64.7 \\
\hline Stage 4 & 6 & 35.3 & 11 & 77.4 \\
\hline Stage 5 & 14 & 22.6 & 48 & \\
\hline
\end{tabular}

The data presented in [Table 7] revealed that

$17.1 \%$ of stage 2 CKD cases had preserved ejection fraction and $64.3 \%$ of stage $2 \mathrm{CKD}$ cases were having reduced ejection function.

$35.7 \%$ of stage $3 \mathrm{CKD}$ cases had preserved ejection fraction and $64.7 \%$ of stage $3 \mathrm{CKD}$ cases were having reduced ejection function

$35.3 \%$ of stage 4 CKD cases had preserved ejection fraction and $64.7 \%$ of stage $4 \mathrm{CKD}$ cases were having reduced ejection function

$22.6 \%$ of stage 5 CKD cases had preserved ejection fraction and $77.4 \%$ of stage $5 \mathrm{CKD}$ cases were having reduced ejection function.

Table 8: Data comparing of severity of CKD with 2-D ECHOLVH/LV function ( $\mathrm{N}=100)$

\begin{tabular}{|l|l|l|l|}
\hline $\begin{array}{l}\text { Stages of } \\
\text { CKD }\end{array}$ & 2-D ECHO-LVH/LV function & $\boldsymbol{f}$ & $\mathbf{\%}$ \\
\hline Stage 2 & Mild concentric LVH ,gr.1 LVDD & 6 & 85.7 \\
\cline { 2 - 4 } & Normal echo & 1 & 14.3 \\
\hline Stage 3 & Mild concentric LVH ,gr.1 LVDD & 9 & 64.3 \\
\cline { 2 - 4 } & $\begin{array}{l}\text { Moderate LV systolic dysfunction } \\
\text { gr.1 LVDD }\end{array}$ & 2 & 14.3 \\
\cline { 2 - 4 } & Normal echo & 3 & 21.4 \\
\hline \multirow{5}{*}{ Stage 4 } & Mild concentric LVH,gr.1 LVDD & 11 & 64.7 \\
\cline { 2 - 4 } & $\begin{array}{l}\text { Moderate LV systolic dysfunction } \\
\text { gr.1 LVDD }\end{array}$ & 3 & 17.6 \\
\cline { 2 - 4 } & Global hypokinesia & 2 & 11.8 \\
\cline { 2 - 4 } & Normal echo & 1 & 5.9 \\
\hline & Concentric LVH gr.1 LVDD & 5 & 8.1 \\
\cline { 2 - 4 } & Mild concentric LVH,gr1 LVDD & 10 & 16.1 \\
\cline { 2 - 4 } & $\begin{array}{l}\text { Moderate LV systolic dysfunction } \\
\text { gr.1 LVDD }\end{array}$ & 28 & 45.2 \\
\cline { 2 - 4 } & $\begin{array}{l}\text { Severe LV systolic dysfunction, } \\
\text { dilated LA/LV }\end{array}$ & 7 & 11.3 \\
\cline { 2 - 4 } & Global hypokinesia & 8 & 14.5 \\
\cline { 2 - 4 } & Dilated LA/LV & 2 & 3.2 \\
\cline { 2 - 4 } & Normal echo & & 1.6 \\
\hline
\end{tabular}

2-D ECHO-LVH/LV function revealed around $6 \%$ of stage 2 CKD cases had Mild concentric LVH, gr.1 LVDD, among stage 3 CKD cases around $64.3 \%$ of the cases had Mild concentric LVH, gr.1 LVDD and 14\% of them had Moderate LV systolic dysfunction gr.1 LVDD, among stage 4 CKD cases around $11.2 \%$ of the cases had Global hypokinesia and among stage 5 CKD cases around $8.1 \%$ of the cases had Concentric LVH gr.1 LVDD, $11.3 \%$ of cases had Severe LV systolic dysfunction, dilated LA/LV and , $1.6 \%$ of them had Dilated LA/LV.

\section{Discussion}

\section{Samples distribution characteristics}

In our study, most of the (54.0\%) of patients were in the age group of 54 and above years, most $(64.0 \%)$ of them were males, about $43.0 \%$ sample having no formal education, around $96 \%$ of them were married. Regarding their personal history, majority $(58.0 \%)$ of them were vegetarians, around $41.0 \%$ were smokers and about $72 \%$ of them were nonalcoholics. Regarding past medical history, majority of them have hypertension, $48 \%$ of them are diabetic and only $3 \%$ of them had history of Tuberculosis.

The study conducted by Kartheek et al, ${ }^{[20]}$ in 2019 had finding similar to our study. The results revealed that, majority $(68.0 \%)$ of sample were males, around $42 \%$ of the sample had hypertension and around $20 \%$ of them were diabetic. A research done by Chillo\&Mujuni, et al, ${ }^{[21]}$ in year 2018 majority of the sample belonged to the age group of 48 and above, around $54.5 \%$ of the samples were males and around $98.4 \%$ of the samples were hypertensive and about $22.8 \%$ of them were diabetics.

\section{General examination and laboratory findings}

In our study, mean body weight of sample were 55.0 \pm 8.42 $\mathrm{Kg}$, the mean S.B.P (mmHg)of the sample was $144.56 \pm 19.88$ $\mathrm{mmHg}$, the mean D.B.P (mmHg)of the sample was $91.02 \pm 9.23 \mathrm{mmHg}$.

In the present study, the mean Haemoglobin $(\mathrm{gms} \%)$ of the sample was $9.19 \pm 2.35 \mathrm{gms} \%$, the mean urea $(\mathrm{mg} / \mathrm{dl})$ value of the sample was $129.74 \pm 66.09 \mathrm{mg} / \mathrm{dl}$, the mean $\mathrm{S}$. creatinine $(\mathrm{mg} / \mathrm{dl})$ value of sample was $5.77 \pm 4.35 \mathrm{mg} / \mathrm{dl}$, the mean Serum sodium (m mol/L) value of the sample was $138.04 \pm 5.35 \mathrm{~m} \mathrm{~mol} / \mathrm{L}$ and the mean Serum potassium $(\mathrm{m}$ $\mathrm{mol} / \mathrm{L}$ ) value of the sample was $4.69 \pm 0.87 \mathrm{~m} \mathrm{~mol} / \mathrm{L}$.

The study conducted by Kartheek et al, ${ }^{[20]}$ in 2019 had mean body weight of $58.09 \pm 8.03 \mathrm{Kg}$, the mean S.B.P $(\mathrm{mmHg})$ of the sample was $148.16 \pm 18.22 \mathrm{mmHg}$, the mean D.B.P (mmHg) of the sample was $93.26 \pm 10.68 \mathrm{mmHg}$. The mean Haemoglobin $(\mathrm{gms} \%)$ of the sample was $7.41 \pm 1.60 \mathrm{gms} \%$, the mean Serum creatinine $(\mathrm{mg} / \mathrm{dl})$ value of the sample was $6.86 \pm 1.69 \mathrm{mg} / \mathrm{dl}$, the mean Serum sodium $(\mathrm{m} \mathrm{mol} / \mathrm{L})$ value of the sample was $133.54 \pm 18.26 \mathrm{~m} \mathrm{~mol} / \mathrm{L}$ and the mean Serum potassium $(\mathrm{m} \mathrm{mol} / \mathrm{L})$ value of the sample was $4.57 \pm 0.87 \mathrm{~m} \mathrm{~mol} / \mathrm{L}$.

In the study conducted by Vankayala et al, ${ }^{[22]}$ in 2019 the mean SBP (mmHg) of the sample was $153.72 \pm 21.97 \mathrm{mmHg}$, the mean DBP (mmHg) of the sample was 93.12 \pm 7.83 $\mathrm{mmHg}$. the mean Hemoglobin $(\mathrm{gms} \%)$ of the sample was $8.52 \pm 0.78 \mathrm{gms} \%$, the mean urea $(\mathrm{mg} / \mathrm{dl})$ value of the sample was $88.22 .74 \pm 22.90 \mathrm{mg} / \mathrm{dl}$, the mean $\mathrm{S}$. creatinine $(\mathrm{mg} / \mathrm{dl})$ measurement of the sample was $6.82 \pm 2.12 \mathrm{mg} / \mathrm{dl}$. This research done by Laddha, et al, ${ }^{[23]}$ in year 2014 revealed that the mean Haemoglobin (gms\%) was $7.78 \pm 1.84 \mathrm{gms} \%$, the mean Serum creatinine $(\mathrm{mg} / \mathrm{dl})$ value was $10.35 \pm 5.56 \mathrm{mg} / \mathrm{dl}$ and the mean blood urea $(\mathrm{mg} / \mathrm{dl})$ value of the sample was 151.7. $\pm 51.37 \mathrm{mg} / \mathrm{dl}$.

Distribution of sample based on stages of CKD

In our current study $7 \%$ of the patients of CKD was in stage 
2 that is G.F.R is $60-89 \% \mathrm{ml} / \mathrm{min}$, and $14 \%$ of the CKD patients was in stage 3 that is (G.F.R is $30-59 \%$ ML/Min/1.73 $\mathrm{M}^{2}$ ), and other $17 \% \mathrm{CKD}$ patients was in the stage 4 that is (GFR is $15-29 \% \mathrm{Ml} / \mathrm{Min} / 1.73 \mathrm{M}^{2}$ ) and all others $62 \%$ CKD patients was in stage 5 that is GFR is $<15 \%$ $\mathrm{Ml} / \mathrm{Min} / 1.73 \mathrm{M}^{2}$.

This research conducted by Reddy et al, ${ }^{[24]}$ in 2018 carried out among $100 \mathrm{CKD}$ cases supported the findings of our current study. The results revealed that, $9 \%$ of the cases were in stage II (GFR60-89\% ml/min/1.73 $\mathrm{m}^{2}$ ), $17 \%$ of cases were in stage III (GFR $30-59 \% \mathrm{ml} / \mathrm{min} / 1.73 \mathrm{~m}^{2}$ ), $32 \%$ of the cases were in the stage IV (GFR 15-29\% Ml/Min/1.73 $\mathrm{M}^{2}$ ) and majority $(42 \%)$ of them were in the stage V of CKD $(<16 \%$ $\mathrm{Ml} / \mathrm{Min} / 1.73 \mathrm{M}^{2}$ ). I.M. conducted a research in 2018, ${ }^{[25]}$ based on GFR rate. Around $22 \%$ of cases were included in group 1 included GFR 89-45Ml/Min/1.73 $\mathrm{M}^{2}, 68 \%$ of cases were included in group 2 included GFR 44-15M1/Min/1.73 $\mathrm{M}^{2}$ and about $10 \%$ of the sample were included in group 3 GFR $<15 \mathrm{ml} / \mathrm{min} / 1.73 \mathrm{~m}^{2}$.

\section{Comparison of severity of CKD with LVH status on ECG} In our study, $1 \%$ of stage 2 CKD cases had LVH and $6 \%$ of stage 2 CKD cases were not having LVH, In stage 3 of CKD $3 \%$ of cases had LVH \& $11 \%$ of CKD stage 3 cases were not having $\mathrm{LVH}, 7 \%$ of stage $4 \mathrm{CKD}$ cases had $\mathrm{LVH}$ and $10 \%$ of stage $4 \mathrm{CKD}$ cases were not having $\mathrm{LVH}$ and around $54 \%$ of stage $5 \mathrm{CKD}$ cases had $\mathrm{LVH}$ and $8 \%$ of stage $5 \mathrm{CKD}$ cases were not having LVH.

Study conducted by Vankayala et alin2019, ${ }^{[22]}$ revealed that, $3 \%$ of CKD stage 3 cases had LVH \& $38 \%$ of CKD stage 3 cases were not having LVH, $39 \%$ of stage $4 \mathrm{CKD}$ cases had $\mathrm{LVH}$ and $43 \%$ of stage $4 \mathrm{CKD}$ cases were not having LVH and around $59 \%$ of stage $5 \mathrm{CKD}$ cases had LVH and $19 \%$ of stage $5 \mathrm{CKD}$ cases were not having LVH. A study was conducted by Amoako et al. ${ }^{[26]}$ in 2017in 203 CKD cases. The study revealed that, $12.5 \%$ of stage $3 \mathrm{CKD}$ cases had $\mathrm{LVH}$ and $15.7 \%$ of stage $3 \mathrm{CKD}$ cases were not having LVH, $5.7 \%$ of stage 4 CKD cases had LVH and $6.0 \%$ of stage $4 \mathrm{CKD}$ cases were not having LVH and around $81.8 \%$ of stage $5 \mathrm{CKD}$ cases had LVH and $78.3 \%$ of stage $5 \mathrm{CKD}$ cases were not having LVH.

\section{Comparison of severity of CKD with condition of ejection \\ fraction}

In the present study, $17.1 \%$ of stage 2 CKD cases had preserved ejection fraction and $64.3 \%$ of stage 2 CKD cases were having reduced ejection function, $35.7 \%$ of stage 3 CKD cases had preserved ejection fraction and $64.7 \%$ of stage $3 \mathrm{CKD}$ cases were having reduced ejection function, $35.3 \%$ of stage $4 \mathrm{CKD}$ cases had preserved ejection fraction and $64.7 \%$ of stage 4 CKD cases were having reduced ejection function and around $22.6 \%$ of stage 5 CKD cases had preserved ejection fraction and $77.4 \%$ of stage $5 \mathrm{CKD}$ cases were having reduced ejection function.

Smith et al, ${ }^{[27]}$ in 2013 found that $54.7 \%$ of stage $1 \mathrm{CKD}$ cases had preserved ejection fraction and $45.3 \%$ of stage 1 CKD cases were having reduced ejection function, $57.1 \%$ of stage $2 \mathrm{CKD}$ cases had preserved ejection fraction and $42.9 \%$ of stage 2 CKD cases were having reduced ejection function, $60.1 \%$ of stage $3 \mathrm{CKD}$ cases had preserved ejection fraction and $63.6 \%$ of stage 3 CKD cases were having reduced ejection function, $66.0 \%$ of stage $4 \mathrm{CKD}$ cases had preserved ejection fraction and $34.0 \%$ of stage 4 CKD cases were having reduced ejection function and around $26.7 \%$ of stage 5 CKD cases had preserved ejection fraction and 74.3 $\%$ of stage $5 \mathrm{CKD}$ cases were having reduced ejection function.

\section{Comparison of severity of CKD with 2-D ECHO-} LVH/LV function

In our study, around $6 \%$ of stage 2 CKD cases had Mild concentric LVH ,gr1 LVDD, among stage 3 CKD cases around $64.3 \%$ of the cases had Mild concentric LVH ,gr1 LVDD and $14 \%$ of them had Moderate LV systolic dysfunction gr.1 LVDD, among stage 4 CKD cases around $11.2 \%$ of the cases had Global hyperkinesias and among stage 5 CKD cases around $8.1 \%$ of the cases had Concentric LVH gr.1 LVDD, $11.3 \%$ of cases had Severe LV systolic dysfunction, dilated LA/LV and , $1.6 \%$ of them had Dilated LA/LV.

Reddy et al, ${ }^{[24]}$ in 2017 carried out similar study among 50 CKD cases and Echocardiography was performed to rule out the cardiac dysfunction. The study finding reveals that, around $47 \%$ of the CKD cases had Concentric LVH, $22 \%$ of them had Dilated LA and 18\% them had dilated LA and 27.5 of the CKD cases had systolic dysfunction. Kartheek et al, ${ }^{[20]}$ showed that, $92 \%$ of CKD cases had LVH, $16 \%$ of the cases had Global hypokinesia and $4 \%$ of the cases had LV systolic dysfunction.

\section{Conclusion}

Left ventricular hypertrophy and dysfunction is a veryimportant preventive feature of CKD associated cardiomyopathy. It is defined as the final outcome of pathophysiological related singling pathways that play a vital role inmyocardial cell thickening and LV concentric remodelling. There is a increased chance of left ventricular hypertrophy in CKD patients. With respect to category of chronic kidney disease, the LVH prevalence is progressively increases with increasing severity of CKD (chronic kidney disease).Patients of CKD due to adverse effects causing increased thickness of left ventricle that further causing myocardial cell distortion and leading to systolic and diastolic function alterationthat occurring very often. Blood pressure control is very important step to forestall the development of CKD and other relateddamage of end organs.The lower the GFR, the more severe the LV diastolic dysfunction. The LV diastolic dysfunction is more, if there is association of increased hypertension and anemia. So, early identification \& cure of above conditions can retard the cardiovascular mortality and morbidity. At early stage if identification have been donefor $\mathrm{LVH} \&$ accordingly interventions should be done to avoid and/or regression of LVH should be encouraged.Echocardiography provides a simple, non-invasive technique that can identify even asymptomatic patients at a prior stage of CKD.Finally, the cure of the Left ventricle increased thickness is mainly prevented by blood pressure control and improvement in 
anaemia, \& optimization of renal additional therapy maximization.

\section{References}

1. Barsoum RS. Chronic Kidney Disease in the Developing World. New England Journal of Medicine. 2006 Mar 9;354(10):997-9.

2. Levin A. Anemia and left ventricular hypertrophy in chronic kidney disease populations: A review of the current state of knowledge. Kidney International. 2002 May 1;61:S35-8.

3. Hung M-J, Yang N-I, Wu I-W, Cheng C-W, Liu P-C, Chen S-J, et al. Three-dimensional echocardiographic assessment of left ventricular remodeling in predialysis chronic kidney disease patients. J Nephrol. $2012 \mathrm{Feb} ; 25(1): 96-106$.

4. Otsuka T, Suzuki M, Yoshikawa H, Sugi K. Left ventricular diastolic dysfunction in the early stage of chronic kidney disease. J Cardiol. 2009 Oct;54(2):199-204.

5. Gluba-Brzózka A, Michalska-Kasiczak M, Franczyk-Skóra B, Nocuń M, Banach M, Rysz J. Markers of increased cardiovascular risk in patients with chronic kidney disease. Lipids Health Dis. 2014 Aug 21;13:135.

6. Hida S, Chikamori T, Tanaka H, Igarashi Y, Hatano T, Usui Y, et al. Diagnostic value of left ventricular function after adenosine triphosphate loading and at rest in the detection of multi-vessel coronary artery disease using myocardial perfusion imaging. J NuclCardiol. 2009 Feb;16(1):20-7.

7. Agarwal S, Dangri P, Kalra O, Rajpal S. Echocardiographic Assessment of Cardiac Dysfunction in Patients of Chronic Renal Failure. 2003;4(4):8.

8. Dangri P, Agarwal S, Kalra O, Rajpal S. Echocardiographic assessment of left ventricular hypertrophy in patients of chronic renal failure. 2003;6.

9. Dahan M, Siohan P, Viron B, Michel C, Paillole C, Gourgon R, et al. Relationship between left ventricular hypertrophy, myocardial contractility, and load conditions in hemodialysis patients: An echocardiographic study. American Journal of Kidney Diseases. 1997 Dec 1;30(6):780-5.

10. Datta S, Abraham G, Mathew M, Somasundaram H, Muralidharan T, Moorthy A, et al. Correlation of Anemia, Secondary Hyperparathyroidism with Left Ventricular Hypertrophy in Chronic Kidney Disease Patients. 2006;54:5.

11. Mailloux LU, Levey AS. Hypertension in patients with chronic renal disease. American Journal of Kidney Diseases. 1998 Nov 1;32(5):S120-41.

12. Meyer KB, Levey AS. Controlling the epidemic of cardiovascular disease in chronic renal disease: report from the National Kidney Foundation Task Force on cardiovascular disease. J Am SocNephrol. 1998 Dec;9(12 Suppl):S31-42.

13. Parfrey PS, Harnett JD, Griffiths SM, Taylor R, Hand J, King A, et al. The clinical course of left ventricular hypertrophy in dialysis patients. Nephron. 1990;55(2):114-20.

14. Foley RN, Parfrey PS, Harnett JD, Kent GM, Martin CJ, Murray DC, et al. Clinical and echocardiographic disease in patients starting end-stage renal disease therapy. Kidney Int. 1995 Jan;47(1):186-92.

15. Levy D, Savage DD, Garrison RJ, Anderson KM, Kannel WB, Castelli WP. Echocardiographic criteria for left ventricular hypertrophy: the Framingham Heart Study. Am J Cardiol. 1987 Apr 15;59(9):956-60.

16. Paoletti E, Bellino D, Cassottana P, Rolla D, Cannella G. Left ventricular hypertrophy in nondiabetic predialysis CKD. Am J Kidney Dis. 2005 Aug;46(2):320-7.

17. Levy D, Garrison RJ, Savage DD, Kannel WB, Castelli WP. Prognostic implications of echocardiographically determined left ventricular mass in the Framingham Heart Study. N Engl J Med. 1990 May 31;322(22):1561-6.

18. London GM, Pannier B, Guerin AP, Blacher J, Marchais SJ, Darne B, et al. Alterations of Left Ventricular Hypertrophy in and Survival of Patients Receiving Hemodialysis: Follow-up of an Interventional Study. JASN. 2001 Dec 1;12(12):2759-67.

19. Levey AS, Eckardt K-U, Tsukamoto Y, Levin A, Coresh J, Rossert J, et al. Definition and classification of chronic kidney disease: A position statement from Kidney Disease: Improving Global Outcomes (KDIGO). Kidney International. 2005 Jun;67(6):2089-100.

20. Kartheek ASV, Reddy VCS. Assessment of cardiac dysfunction in patients with end stage renal disease in a tertiary care hospital. J Evid Based Med Healthc. 2019 Dec 6;6(24):1668-72.

21. Chillo P, Mujuni E. Prevalence and predictors of left ventricular dysfunction among patients with chronic kidney disease attending Muhimbili National Hospital in Tanzania \&mdash;\&nbsp;a crosssectional study [Internet]. Research Reports in Clinical Cardiology 2018 [cited 2019 Oct 21]. Available from: https://www.dovepress.com/prevalence-and-predictors-of-leftventricular-dysfunction-among-patien-peer-reviewed-article-RRCC

22. Vankayala A, Behera KL, Raju DSSK, Sayana SB. A study on the left ventricular hypertrophy among the patients of chronic kidney disease stage third to five. International Journal of Research in Medical Sciences. 2019 Apr 26;7(5):1511-4.

23. Laddha M, Sachdeva V, Diggikar PM, Satpathy PK, Kakrani AL. Echocardiographic assessment of cardiac dysfunction in patients of end stage renal disease on haemodialysis. J Assoc Physicians India. 2014 Jan;62(1):28-32.

24. Reddy KV, C A J. Prevalence of anemia and left ventricular hypertrophy and their correlation in chronic kidney disease patients. Medpulse-International Medical Journal [Internet]. 2018 May [cited 2019 Sep 20];6(2). Available from: https://www.medpulse.in/Medicine/html_6_2_11.php

25. Rudenko TE, Kamyshova ES, Vasilyeva MP, Bobkova IN, Solomakhina NI, Shvetsov MY. Risk factors for diastolic left ventricular myocardial dysfunction in patients with chronic kidney disease. TerArkh. 2018 Sep 20;90(9):60-7.

26. Amoako YA, Laryea DO, Bedu-Addo G, Nkum BC, Plange-Rhule J. Left ventricular hypertrophy among chronic kidney disease patients in Ghana. Pan Afr Med J. 2017;28:79.

27. Smith David H., Thorp Micah L., Gurwitz Jerry H., McManus David D., Goldberg Robert J., Allen Larry A., et al. Chronic Kidney Disease and Outcomes in Heart Failure With Preserved Versus Reduced Ejection Fraction. Circulation: Cardiovascular Quality and Outcomes. 2013 May 1;6(3):333-42.

Copyright: () the author(s), 2019. It is an open-access article distributed under the terms of the Creative Commons Attribution License (CC BY 4.0), which permits authors to retain ownership of the copyright for their content, and allow anyone to download, reuse, reprint, modify, distribute and/or copy the content as long as the original authors and source are cited.

How to cite this article: Gupta R, Kumar A. Assessment of Left Ventricular Hypertrophy and Dysfunction in Patients of Chronic Kidney Disease.Acad. J Med. 2019;2(2):211-16.

DOI: dx.doi.org/10.21276/ajm.2019.2.2.53

Source of Support: Nil, Conflict of Interest: None declared. 